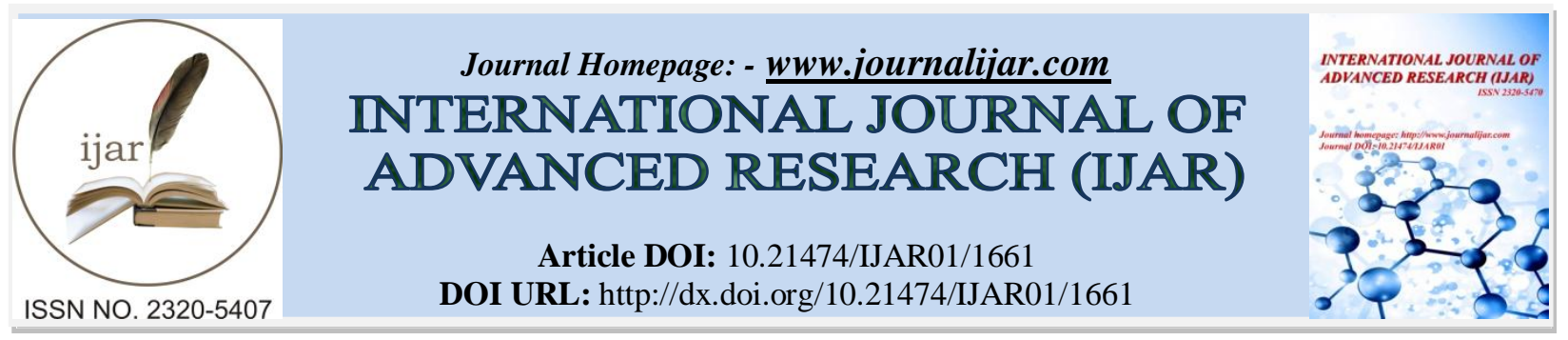

RESEARCH ARTICLE

\title{
CONSTITUTIONAL-LEGAL STATUS OF NATURAL RESOURCES: THEORETICAL AND COMPARATIVE-LEGAL ANALYSIS.
}

Akmal Abdusattarov Mirzaakbarovich.

Senior science researcher at Tashkent State University of Law.

\section{Manuscript Info}

Manuscript History

Received: 12 July 2016

Final Accepted: 19 August 2016

Published: September 2016

\begin{abstract}
The article on the basis of the Constitution of the Republic of Uzbekistan to learn the basics of environmental duties and legal obligations. The article 150 of the Constitution of foreign countries for the first time environmental liabilities, structural analysis, and they are structured. In addition, based on the experience of foreign countries, developed recommendations on the application of national legislation.
\end{abstract}

Key words:-

Constitution, comparative analysis of the environmental liability, environmental protection, compensation, environmental taboos.

Copy Right, IJAR, 2016,. All rights reserved.

Legal status of natural resources was reflected in the provisions of Constitution of the Republic of Uzbekistan. In particular, Article 55 of Constitution defines, that land, minerals, water, flora and fauna, and other natural resources are the national wealth, and state guarantees their protection, safeguard and rational use. Natural resources wealth increases the effectiveness of the use of the economic potential of the country.

The Constitution of the Republic of Uzbekistan is rich in natural resources as well as the "national wealth" concept used $^{1}$. The constitutions of foreign countries suffer more than other approaches. In particular, Bulgaria, Estonia, Hungary, Iraq, and the constitutions of Nicaragua "national wealth", Cuba, Mongolia, China and the Basic Law, "the state (public) property," the Constitution of Vietnam, "public property", South Sudan and the constitutions of the Ukraine, "public property" as used in the categories. Analysis of the legislation of foreign countries, their natural resources, the most "state-owned" the application of the concept. In particular, the constitutions that this concept is used in the following countries: Afghanistan (Article 9), Angola (16), Bahrain (11th), Bangladesh (143), Bhutan (Chapter 1, paragraph 12), Brazil (Article 20), Belarus (13), Cambodia (58), Guatemala (121), Hong Kong (7), Ireland (10), Israel (1), Kazakhstan ( Article 613), China (21), Kuwait (21), Kyrgyzstan (12), Liberia (22), Mozambique (97), Oman (11), Namibia (100 Article), the Philippines (Article 11, Section 2), East Timor (Article 139), Qatar (29), Saudi Arabia (14), Spain (132), Syria (Article 14 ), Tajikistan (Article 13), the United Arab Emirates (23), Congo (Article 9) and etc.

1 Rahmonkulov H. Constitution 20 years. Executive Editor: prof. O.Z.Muxammadjonov. Tashkent: Law, 2012. P.60. 
"National wealth" constitutional-legal status of scientific and legal literature, as a rule, cultural, artistic, archaeological and historical valuables as well as a variety of natural resources and natural objects used ${ }^{2}$. Objects of national wealth is an important economic, social, environmental, cultural and educational roles, as well as the national interests of the state, and provide economic and environmental security of the country and the people and create the conditions for the formation of national identity and national consciousness of the person. The object of the national wealth of natural resources as reflected in the unique shape of human living environment, natural resources.

One of the unique features of the status of national wealth for the owner of the object of the national wealth in terms of ensuring the interests of the state and society in accordance with the determination of additional restrictions. Such restrictions, for example, the use of the object of the national wealth, position, and requirements related to the rational use of etc.

The constitutional status of national wealth refers to the use of the interests of all the people of the Republic of Uzbekistan. For example, the natural resources of a separate administrative-territorial unit, enterprise, institution, organization or individual, wealth can not be.

The "national wealth" and "national property" and the differences between the concepts of a constitution-making that it is not surprising that this concept is using. It should be unnoted that this ratio concepts, different aspects studied professor Y.O.Juraev. According to legal scholars, the legal status of the property of the natural resources of the state at the present time is equal to the legal point of view, the concept of public property. As defined by the owner shall be carried out on behalf of the people of the state, however, such a concept is not considered legal category. He is the essence of political nature, the property available to the public imagination. At the same time the government has significantly changed the role of the owner. He is the absolute ownership of natural resources and will be responsible for providing a favorable environment that retains only the control functions. In the field of wildlife management and environmental protection in previous legislative system, which represents the interests of the administrative-command system, which represents the interests of managing the use of natural resources departments. Now, the nature and represent the requirements of the protection of the environment.

The state of natural resources in the exclusive ownership of natural resources, either economic or legal relations of property does not serve as a legal form of implementation. Otherwise, this is an abstract subject that will lead to the establishment of a people's property, and all the people of the state bodies of power and administration on behalf of the owner should master the unlimited powers in the implementation of the functions and this will result in serious consequences. Even in the purely economic sense of the people as the subject of the right of ownership of natural resources will not be billed ${ }^{3}$.

At the same time, unlike scientists in this matter appropriate to shape the direction of the different views of scientists tsivilist. They are in the field of legal regulation of "People", "wealth" or "national wealth" criticism of the use of such terms. According to them, this concept is the use of legal concepts and noaniqlashtiradi will lead to the emergence of abstract arguments and disputes. According to them, the concept of state property represents the full contents of the national wealth, because, as a rule, in full conformity with the interests of the state and public interests. In addition, they say, requires a clear legal sense, the owner of the property, the property right of the people to be the subject of legal, organizational-legal form should be able to have a state of such a nature ${ }^{4}$.

This approach is able to think tsivilistik, science is developed based on the theoretical principles of civil law, the system of legal regulation of social relations, and of course the media will not be considered. However, in terms of constitutional law to prove that the rationale of national sovereignty, and the only source of power in the state as the owner of natural resources and the right to manage this property. The State, in turn, the general method of property

2 Isaev A.S. Forest as a national treasure of Russia // Age of Globalization. - 2011. - №1. - S. 148-158; Melent'ev G.B., Short V.M., Malinin E.N., Samonov A.E. Peat - a national treasure of Russia: prospects for multi-purpose use and environmental safety // Ecology of industrial production. - 2011. - №1. - P. 69-80; Kurmaz V.V., Tsygir A.A. Russian Pacific salmon - a national treasure of Russia // Fisheries. - 2010. - №2. - P.30.

3 Juraev Y.A. Law and Governance in the use and protection of the natural environment of the Republic of Uzbekistan: Author. diss. ... Doctor. jurid. Sciences. - M .: IGP, 1996. - P.30-32. (50).

4 Prokhorova N.A. Concept of "control" in the land law // the State and the right. - 2003. - № 6. - P.93. 
management, and if it meets the interests of the people of legal entities and individuals on the basis of the right to property.

Legal publications, including civil and environmental legislation recognized the existence of dialectical contradictions between the ${ }^{5}$. K.G.Pandakov and A.E.Chernomoretslarning wrote, in this case, the importance of land as a natural object, and national wealth in the first place and use and requires an adaptation of the requirements of the protection of nature ${ }^{6}$.

Today, the people on the recognition of human rights as a subject of research work carried out. In particular, M.P.Fomichenko "People" category of legal shows three main aspects: the political community, the public power source and the subject; regional team, the inhabitants of a particular region; the right to equality and selfdetermination of ethnic political-regional team ${ }^{7}$. National natural resources should be used to the benefit of all citizens of the country.

So the constitutional status of national wealth human rights norms enshrined in public law, based on the sovereignty of natural resources, the country's national interests, economic and environmental security, as well as natural resources, property rights and the interests of the people of the Republic of Uzbekistan ensuring the implementation and use of public interests, as well as natural resources are under state protection.

The context of the current constitutional reform on the one hand, the state parliament of strengthening and expanding the role of the society, on the other hand, the development of natural resources in the country's economic sovereignty and taking into account the position of the heads of diplomatic missions and international organizations accredited in the Republic of Uzbekistan equivalent state-owned land authorizing the sale of the Cabinet of Ministers of the Republic of Uzbekistan in accordance with the purpose of the Oliy Majlis of the Republic of Uzbekistan. For this purpose, the relevant amendments to the Land Code of the Republic of Uzbekistan and the purpose of the amendments.

5 Krasnov N.I. On the relation between land and civil rights during the transition to a market economy // State and right. - 1994. - № 7. - S. 54 .; Baranovska I.G. Civil-law regulation of land lease contract in Russia: Diss. ... Cand. jurid. Sciences. - M .: SRI, 2013. - p.49 .; Vorontsov S.A. Formation and development of land relations in Russia: History and Modernity: Author. diss. ... Cand. jurid. Sciences. - Krasnodar, 2008 - C.13.

6 Pandakov K.G, Chernomorets A.E. Agrarian Land Reform: Legislation, Theory, Practice. Saratov, 2004. - P. $22-$ 23.

7 Fomichenko M.P. Peoples' Rights in the Russian Federation (the constitutional and legal aspects): Abstract. Dis. ... Dr. jurid. Sciences. - M., 2006. - P.11. 